\title{
IMPLEMENTASI KEBIJAKAN PENYELENGGARAAN PROGRAM JAMINAN KESEHATAN DAERAH KOTA BEKASI
}

\author{
Kamal Alamsyah ${ }^{1)}$, Ellya Niken Prastiwi ${ }^{2)}$, Ummu Salamah $^{3)}$ \\ ${ }^{123}$ Program Doktor Ilmu Sosial Pascasarjana Universitas Pasundan \\ Apih.amay007@gamil.com \\ ABSTRAK
}

Masalah pokok dalam penelitian ini adalah belum terlaksananya secara efektif kebijakan/program Jaminan Kesehatan Daerah Berbasis Kartu Keluarga Dan Nomor Induk Kependudukan di Kota Bekasi. Metode penelitian yang digunakan oleh peneliti adalah dekriptif analisis dengan pendekatan penelitiannya adalah kualitatif. Metode dan pendekatan ini dipilih dengan pertimbangan bahwa diharapkan dapat diperoleh data yang sebenar-benarnya dan mampu mengkaji masalah penelitian secara mendalam sehingga dapat diperoleh hasil yang diharapkan. Hasil penelitian dapat dijelaskan bahwa terdapat faktor-faktor dalam mengimplementasi kebijakan Jaminan Kesehatan Daerah Kota Bekasi yaitu faktor standar, ukuran dan tujuan kebijakan, ukuran dan tujuan kebijakan, sumber-sumber daya, karakteristik organisasi pelaksana, sikap para pelaksana, komunikasi antar organisasi terkait dan kegiatan-kegiatan pelaksanaan, dan lingkungan sosial, ekonomi serta politik. Namun dalam implementasinya faktor-faktor tersebut belum seluruhnya berjalan secara efektif, yaitu faktor sumber daya kebijakan dan faktor karakteristik agen pelaksana sehingga masih terdapat masalah yang dihadapi berkaitan dengan implementasi kebijakan Jaminan Kesehatan Daerah. Hal ini tentunya juga belum dapat memberikan jalan terbaik dalam memberikan pelayanan publik yang berkualitas khususnya berkaitan dengan Program Jaminan Kesehatan Daerah Bagi Masyarakat Berbasis Kartu Keluarga dan Nomor Induk Kependudukan.

Kata Kunci : Strategi implementasi kebijakan

\begin{abstract}
The main problem in this research is the ineffectiveness of policies / programs based on Family Card and Population Identification Number in the City of Bekasi. The research method used by researchers is descriptive analysis with a qualitative research approach. This method and approach was chosen with the consideration that it is expected that real data can be obtained and able to study the research problem in depth so that the expected results can be obtained. The results of the study can be explained that there are factors that cause the implementation of the Bekasi City Health Insurance policy not yet effective, namely the standard factors, the size and objectives of the policy, the size and objectives of the policy, resources, characteristics of the implementing organization, the attitude of the implementers, communication between related organizations and implementation activities, and social, economic and political environment. However, in its implementation these factors have not yet been carried out effectively, namely the policy resource factor and the implementing agent characteristic factors so that there are still problems encountered relating to the implementation of the Regional Health Insurance policy. This of course also cannot provide the best way to provide quality public services, especially with regard to the Regional Health Insurance Program for People Based on Family Cards and Population Identification Numbers.
\end{abstract}

Keywords: Policy implementation strategy 


\section{PENDAHULUAN}

Penyelenggaraan Jaminan kesehatan semesta dicanangkan pertama kali oleh pemerintah Indonesia pada tahun 2004 sebagai bagian dari kewajiban pemerintah yang diamanatkan oleh konstitusi untuk memberi perlindungan kepada seluruh warga negara dari berbagai permasalahan kesehatan. Undang-undang No 40/2004 tentang Sistem Jaminan Sosial Nasional membuka jalan bagi upaya reformasi, khususnya yang berkaitan dengan sistem kesehatan. Pada tahap awal penyelenggaraannya, jaminan kesehatan semesta ini diselenggarakan melalui program jaminan kesehatan dengan nama jaminan kesehatan masyarakat miskin (Askeskin) dan dikelola oleh BUMN, yaitu PT. Askes. Dalam perkembangannya, program ini berubah nama menjadi program jaminan kesehatan masyarakat atau Jamkesmas, dengan menargetkan masyarakat miskin dan hampir miskin sebagai penerima manfaat program. Pada saat itu, Jamkesmas menanggung sekitar 76, 4 juta penduduk Indonesia. Meskipun Jamkesmas menanggung 76, 4 juta penduduk miskin di Indonesia, pada kenyataannya, ada cukup banyak penduduk yang berhak namun belum tercakup sebagai penerima manfaat Jamkesmas. Berdasarkan keputusan menteri kesehatan tentang pedoman operasional Jamkesmas, penduduk yang tidak tercakup ini menjadi tanggung jawab pemerintah daerah. Undang-undang nomor 23 tahun 2014 tentang Otonomi Daerah juga telah membuka kesempatan bagi pemerintah daerah untuk memformulasikan skema jaminan sosial tersendiri, termasuk menyelenggarakan program jaminan kesehatan untuk masyarakat di daerahnya.

Jaminan kesehatan merupakan salah satu bagian yang berperan besar dalam meningkatkan derajat kesehatan masyarakat. Keberhasilan pelaksanaan jaminan kesehatan yang diterapkan di suatu negara tergantung dari pencapaian berbagai faktor dalam jaminan kesehatan tersebut, yang meliputi beberapa hal seperti pelayanankesehatan, sumberdayamanusiadananggaran, sumber daya peralatan kesehatan, dan regulasi. Sehingga memunculkan sinergi antara semua faktor yang mendukung pelaksanaan jaminan kesehatan agar berjalan dengan baik. Berbagai negara di dunia mempunyai mekanisme sistem pelayanan kesehatan dan pendistribusian jaminan kesehatan yang berbeda-beda. Penyelenggaraan jaminan kesehatan semakin diutamakan oleh pemerintah Indonesia sejak tahun 2004 sebagai bagian dari kewajiban pemerintah untuk memberikan perlindungan kepada seluruh warga negara Indonesia dalam menghadapi berbagai risiko dan permasalahan kesehatan. Pada awalnya pelaksanaan program jaminan kesehatan merupakan salah satu upaya yang dilaksanakan oleh pemerintah untuk mengatasi ketidakmampuan masyarakat khususnya masyarakat miskin dalam mengakses dan membayar layanan kesehatan. Namun saat ini sedang berada dalam masa transisi menuju cakupan pelayanan kesehatan semesta. Undang-Undang Nomor No. 40 Tahun 2004 tentang Sistem Jaminan Sosial Nasional (UU SJSN) telah menjawab prinsip dasar program jaminan kesehatan dengan mewajibkan setiap penduduk Indonesia harus memiliki akses pelayanan kesehatan secara komprehensif.

Pemerintah Kota Bekasi sebagai salah satu pemerintah daerah di Indonesia merasa memiliki tanggung jawab dalam memberikan jaminan kesehatan didaerahnya. Hal ini mendorong Kota Bekasi untuk menyelenggarakan kebijakan program pelayanan jaminan kesehatan daerah di Kota Bekasi dengan dikeluarkannya Peraturan Walikota Bekasi Nomor 27. A Tahun 2017 Tentang Penyelenggaraan Program Jaminan Kesehatan Daerah Bagi Masyarakat Berbasis Kartu Keluarga Dan Nomor Induk Kependudukan di Kota Bekasi. Dalam rangka mewujudkan Visi dan Misi Kota Bekasi yaitu Cerdas, Kreatif, Maju, Sejahtera dan Ihsan, Jaminan Kesehatan Daerah yang berupa Kartu Sehat 
Kebijakan: Jurnal Ilmu Administrasi

Volume 12, Nomor 2, Juni 2021

E-ISSN: 2656-2820

P-ISSN 1829-5762

Kota Bekasi berbasis NIK adalah kebijakan program jaminan kesehatan masyarakat daerah bagi masyarakat yang dibiayai oleh daerah diluar kuota BPJS. Kartu Sehat Kota Bekasi berbasis NIK ini dikembangkan sebagai upaya untuk memberikan jaminan kesehatan bagi warga dengan tujuan pemberian pelayanan kesehatan yang memudahkan dan singkat alur pelayanan nya, sertatujuan lebih khusus adanya kepastian akan layanan kesehatan yang dibutuhkan oleh masyarakat daerah Kota Bekasi. Dengan adanya Kartu Sehat Berbasis NIK ini, Pemerintah Kota Bekasi dan warganya terakomodasi dalam proses pelayanan kesehatan yang prima, dan harapannya dapat meningkatkan nilai dari proses Kota Bekasi yang Maju, Sejahtera, dan Ihsan.

Jamkesda (Kartu Sehat) Kota Bekasi hadir dalam menjawab tantangan tersebut, oleh karena itu penulis merasa perlu melakukan studi implementasi agar dapat dijadikan bahan masukan dalam rangka meningkatkan kualitas kesehatan masyarakat. Berkaitan dengan program Jaminan Kesehatan Daerah (Kartu Sehat Kota Bekasi) yang di laksanakan oleh Pemerintah Daerah Kota Bekasi, penulis menilai ada beberapa kendala yang dihadapi dalam pelaksanaannya sehingga belum berjalan secara efektif, dalam mewujudkan harapan masyarakat kota Bekasi.Kartu Bekasi Sehat merupakan upaya Pemerintah Kota Bekasi memberikan pelayanan kesehatan bagi seluruh rakyatnya. Program Kartu Bekasi Sehat berbasis NIK adalah terobosan besar. Kartu ini bisa digunakan oleh warga Kota Bekasi tanpa harus membayar premi atau iuran dan tanpa menggunakan rujukan jika ingin menggunakan fasilitas kesehatan di rumah sakit. Pentingnya derajat kesehatan masyarakat menjadi tanggung jawab bersama. Tak hanya pemerintah daerah tapi juga seluruh elemen masyarakat Kota Bekasi. Pemerintah menyediakan sarana dan prasarana kesehatan, mulai dari tenaga medis, layanan kesehatan prima, sarana obat-obatan yang memadai serta fasilitas penunjang kesehatan lainnya. Elemen masyarakat lainnya mendukung dan berperan aktif dalam setiap program. Kartu Bekasi Sehat menuju Kota Bekasi yang cerdas, kreatif, maju, sejahtera dan ihsan

Belum terlaksananya Jaminan Kesehatan Daerah secara efektif di Kota Bekasi terkait implementasi kebijakan pemerintah daerah dalam pelaksanaan Kartu Sehat Kota Bekasi yang belum berjalan secara optimal. Hal ini berkaitan dengan pemahaman terhadap tujuan, isi dan sasaran standar kebijakan Tentang Penyelenggaraan Program Jaminan Kesehatan Daerah Bagi Masyarakat Berbasis Kartu Keluarga dan Nomor Induk Kependudukan di Kota Bekasi yang belum baik. Disamping itu juga permasalahan tersebut juga berkaitan dengan sumber daya manusia, sumber dana dan sarana prasarana yang kurang mendukung terhadap Penyelenggaraan Program Jaminan Kesehatan Daerah Bagi Masyarakat Berbasis Kartu Keluarga dan Nomor Induk Kependudukan di Kota Bekasi.

\section{PENDEKATAN TEORITIS}

Implementasi kebijakan publik ini mengandung suatu hubungan yang memungkinkan tujuan-tujuan atau sasaran yang akan dicapai merupakan hasil akhir dari kegiatan yang dilakukan pemerintah atau eksekutif. Kekurangan atau kesalahan suatu kebijakan publik akan diketahui setelah kebijakan publik itu dilaksanakan, begitu juga suksesnya pelaksanaan kebijakan publik dapat dilihat dari akibat yang ditimbulkan sebagai hasil pelaksanaan suatu kebijakan. Implementasi kebijakan dapat dilaksanakan secara tepat sasaran dan berguna untuk memecahkan suatu permasalahan yang ada, semakin kompleks permasalahan kebijakan dan semakin mendalam analisis yang digunakan maka semakin diperlukan teori dan modal yang mampu menjelaskan. Pelaksanaan atau implementasi kebijakan merupakan bagian yang paling 
Kebijakan: Jurnal Ilmu Administrasi

Volume 12, Nomor 2, Juni 2021

E-ISSN: 2656-2820

P-ISSN 1829-5762

sulit dari proses kegiatan. Implementasi kebijakan memerlukan beberapa persyaratan yang dapat dijadikan acuan untuk mencapai sasaran atau tujuan sebagaimana yang telah ditetapkan dalam rumusan kebijakan. Menurut Van Meter dan Van Horn (1975:463) terdapat enam dimensi dalam mengimplementasikan kebijakan publik sebagai berikut :

1.Policy standards and objectives, which elaborate on the overall goals of the policy decision... to provide concrete and more specific standards for assessing performance;

2.The resources and incentives made available;

3.The quality of inter-organizational relationship (we find in their discussion of this, as in so much of the American literature on implementation, an extensive discussion of aspect of federalism;

4.The characteristics of the implementation agencies, including issues like organizational control but also, going back surely to inter-organizational issues, 'the agency's formal and informal linkages with the "policy-making" or "policy-enforcing" body;

5.The economic, social and political environment; and

6.The 'disposition' or response of the implementers, involving three elements: 'their cognition (comprehension, understanding) of the policy, the direction of their response to it (acceptance, neutrality, rejection) and the intensity of that response.

Pendapat tersebut di atas dapat dijelaskan oleh peneliti bahwa (1) Policy standards and objectives dapat diartikan sebagai tujuan dan standar pencapaian tujuan implementasi kebijakan publik; (2) The resources and incentives dapat diartikan sebagai sumber daya dan insentif implementasi kebijakan publik; (3) The quality of inter-organizational relationship dapat diartikan sebagai kualitas hubungan antar instansi yang terkait dalam proses implementasi kebijakan publik; (4) The characteristics of the implementation agencies dapat diartikan sebagai karakteristik instansi pelaksana kebijakan atau yang lebih dikenal dengan sebutan kedudukan, wewenang dan fungsi masing-masing instansi yang terkait dalam proses implementasi kebijakan publik;

Dimensi lainnya adalah nomor (5) yaitu The economic, social and political environment dapat diartikan sebagai kondisi kehidupan sosial ekonomi masyarakat dalam wilayah implementasi kebijakan publik; dan (6) The 'dispositon' or response of the implementers, involving three elemens: 'their cognition of the policy, the direction of their response to it and the intensity of that response dapat diartikan sebagai kecenderungan tanggungjawab pelaksana kebijakan yang meliputi kesadaran, arahan dan intensitas tanggungjawab terhadap implementasi kebijakan publik. Model pendekatan implementasi kebijakan yang dirumuskan Van Meter dan Van Horn dalam Widodo (2007:15) disebut dengan AModel of the Policy Implementation. Proses implementasi ini merupakan sebuah abstraksi atau performansi suatu pengejewantahan kebijakan yang pada dasarnya secara sengaja dilakukan untuk meraih kinerja implementasi kebijakan yang tinggi yang berlangsung dalam hubungan berbagai variabel. Model ini mengandaikan bahwa implementasi kebijakan berjalan secara linear dari keputusan politik, pelaksana dan kinerja kebijakan publik. Lebih lanjut Van Meter dan Van Horn dalam Widodo (2007:15) menjelaskan bahwa untuk mengefektifkan sebuah implementasi kebijakan dipengaruhi oleh beberapa faktor yang saling berkaitan, faktor tersebut yaitu:

1. Ukuran dan tujuan kebijakan

Kinerja implementasi kebijakan dapat diukur tingkat keberhasilannya jika dan hanya jika ukuran dan tujuan dari kebijakan memang realistis dengan sosio kultur yang mengada di level pelaksana kebijakan. Ketika ukuran kebijakan atau tujuan kebijakan terlalu ideal (bahkan 
Kebijakan: Jurnal Ilmu Administrasi

Volume 12, Nomor 2, Juni 2021

E-ISSN: 2656-2820

P-ISSN 1829-5762

terlalu utopis) untuk dilaksanakan di level warga, maka agak sulit memang merealisasikan kebijakan publik hingga titik yang dapat dikatakan berhasil.

2. Sumber daya

Keberhasilan proses implementasi kebijakan sangat tergantung dari kemampuan memanfaatkan sumber daya yang tersedia. Manusia merupakan sumber daya yang terpenting dalam menentukan suatu keberhasilan proses implementasi. Tahap-tahap tertentu dari keseluruhan proses implementasi menuntut adanya sumber daya manusia yang berkualitas sesuai dengan pekerjaan yang diisyaratkan oleh kebijakan yang telah ditetapkan secara apolitik. Tetapi ketika kompetensi dan kapabilitas dari sumber-sumber daya itu nihil, maka kinerja kebijakan publik sangat sulit untuk diharapkan. Tetapi diluar sumber daya manusia, sumber daya lain yang perlu diperhitungkan juga ialah sumber daya finansial dan sumber daya waktu.

3. Karakteristik Agen Pelaksana

Pusat perhatian pada agen pelaksana meliputi organisasi formal dan organisasi informal yang akan terlibat pengimplementasian kebijakan publik. Hal ini sangat penting karena kinerja implementasi kebijakan (publik) akan sangat banyak dipengaruhi oleh ciri-ciri yang tepat serta cocok dengan para agen pelaksananya. Selain itu, cakupan atau luas wilayah implementasi kebijakan perlu juga diperhitungkan manakala hendak menentukan agen pelaksana. Semakin luas cakupan implementasi kebijakan, maka seharusnya semakin besar pula agen yang dilibatkan.

4. Sikap/Kecenderungan (Disposisi) para Pelaksana

Sikap penerimaan atau penolakan dari (agen) pelaksana akan sangat banyak mempengaruhi keberhasilan atau tidaknya kinerja implementasi kebijakan publik. Hal ini sangat mungkin terjadi oleh karena kebijakan yang dilaksanakan bukanlah hasil formulasi warga setempat yang mengenal betul persoalan dan permasalahan yang mereka rasakan. Tetapi kebijakan yang akan implementor laksanakan adalah kebijakan dari atas (top down) yang sangat mungkin para pengambil keputusannya tidak pernah mengetahui (bahkan tidak mampu menyentuh) kebutuhan, keinginan, atau permasalahan yang warga ingin selesaikan.

5. Komunikasi Antar Organisasi dan Aktivitas Pelaksana

Koordinasi merupakan mekanisme yang ampuh dalam implementasi kebijakan publik. Semakin baik koordinasi komunikasi diantara pihak-pihak yang terlibat dalam suatu proses implementasi, maka asumsinya kesalahan-kesalahan akan sangat kecil untuk terjadi dan begitu pula sebaliknya.

6. Lingkungan Ekonomi, Sosial, dan Politik

Hal terakhir yang perlu juga diperhatikan guna menilai kinerja implementasi publik dalam perspektif yang ditawarkan oleh Van Metter dan Van Horn adalah sejauh mana lingkungan eksternal turut mendorong keberhasilan kebijakan publik yang telah ditetapkan. Lingkungan sosial, ekonomi, dan politik yang tidak kondusif dapat menjadi biang keladi dari kegagalan kinerja implementasi kebijakan. Karena itu, upaya untuk mengimplementasikan kebijakan harus pula memperhatikan kekondusifan kondisi lingkungan eksternal.

Diantara faktor-faktor tersebut secara simultan bekerja dan berinteraksi yang pada gilirannya berpengaruh secara langsung atau tidak langsung terhadap keberhasilan implementasi kebijakan 
Kebijakan: Jurnal Ilmu Administrasi

Volume 12, Nomor 2, Juni 2021

E-ISSN: 2656-2820

P-ISSN 1829-5762

publik, melalui implementasi kebijakan model Van Meter dan Van Horn dapat dijelaskan dan dianalisis dengan mencari keterkaitan antar dimensi yang membentuknya, sehingga memberikan penjelasan tentang optimal atau tidaknya sebuah implementasi kebijakan.

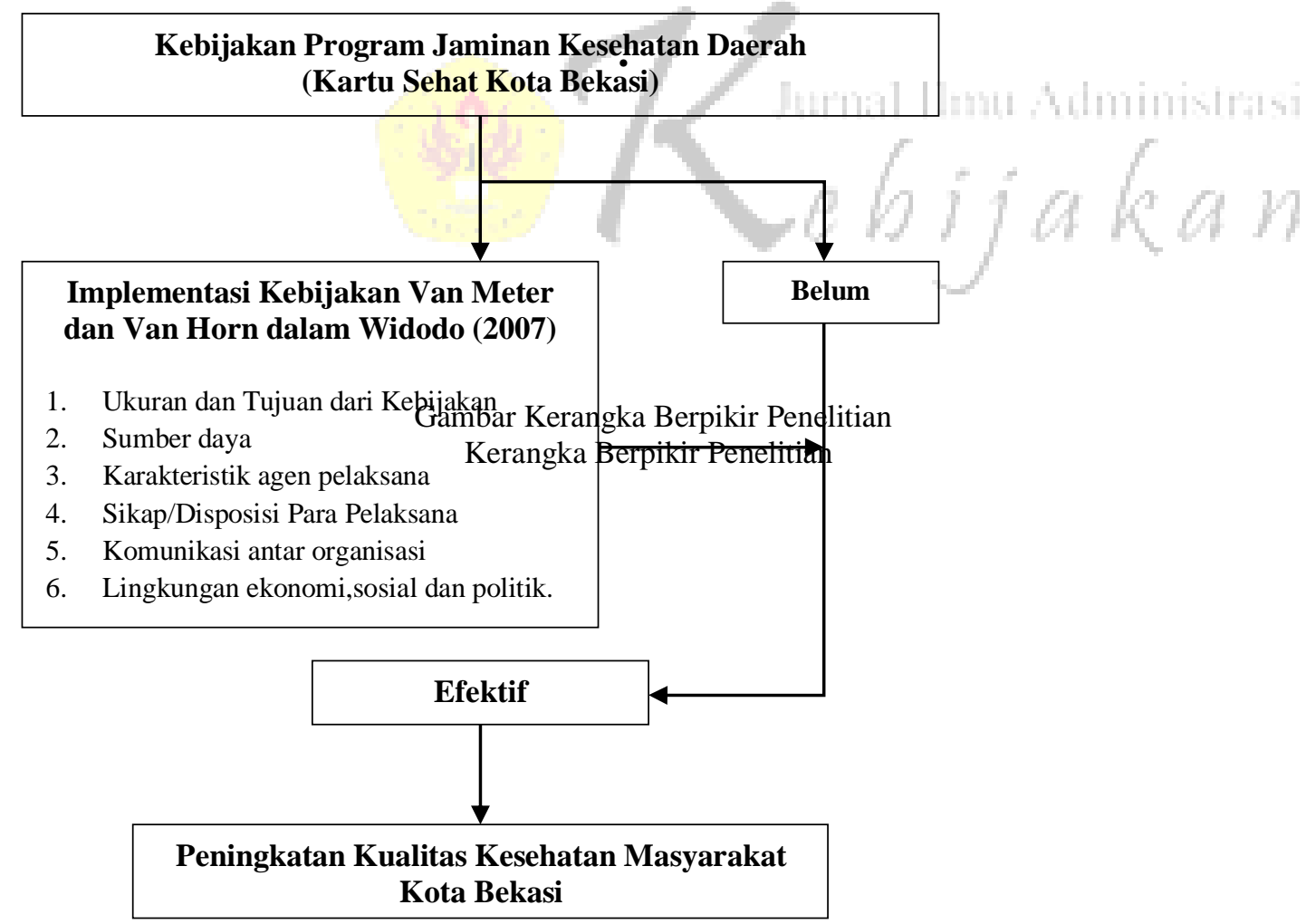

\section{METODE}

Metode penelitian yang digunakan oleh peneliti adalah dekriptif analisis dengan jenis penelitiannya adalah kualitatif. Menurut Moleong (2009:3) bahwa "penelitian kualitatif sebagai prosedur penelitian yang menghasilkan data deskriptif berupa kata-kata tertulis atau lisan dari orangorang dan perilaku yang dapat diamati". Metode kualitatif dipilih dengan pertimbangan bahwa metode ini diharapkan dapat diperoleh data yang sebenar-benarnya dan mampu mengkaji masalah penelitian secara mendalam sehingga dapat diperoleh hasil yang diharapkan. Penggunaan metode penelitian kualitatif ini dirasakan sangat tepat dalam studi ilmu administrasi publik, terutama penelitian yang mencoba untuk mengkaji dan memahami suatu masyarakat.

Jenis pendekatan kualitatif yang digunakan adalah strategi studi kasus model kelembagaan. Peneliti menyelidiki secara cermat suatu program, peristiwa, aktivitas, proses atau sekelompok individu. Kasus-kasus dibatasi dengan waktu dan aktivitas, peneliti mengumpulkan informasi secara lengkap, menggunakan berbagai prosedur pengumpulan data berdasarkan waktu yang telah ditentukan. 
Kebijakan: Jurnal Ilmu Administrasi

Volume 12, Nomor 2, Juni 2021

E-ISSN: 2656-2820

P-ISSN 1829-5762

Analisis data adalah proses menyusun dan menggabungkan data ke dalam pola, tema, kategori, sedangkan penafsiran adalah memberikan makna kepada analisis, menjelaskan pola atau kategori, dan mencari hubungan antara beberapa konsep. Penafsiran menggambarkan perspektif peneliti bukan kebenaran. Analisis dan penafsiran data dalam penelitian kualitatif pada dasarnya bukan merupakan hal yang berjalan bersama, keduanya dilakukan sejak awal penelitian. Analisis data dilakukan agar data yang telah diperoleh akan lebih bermakna. Analisis data merupakan proses penyederhanaan data kedalam bentuk yang lebih mudah dibaca dan diinterprestasikan.

Analisis data penelitian ini, bila dinyatakan dalam bentuk gambar adalah sebagai berikut:

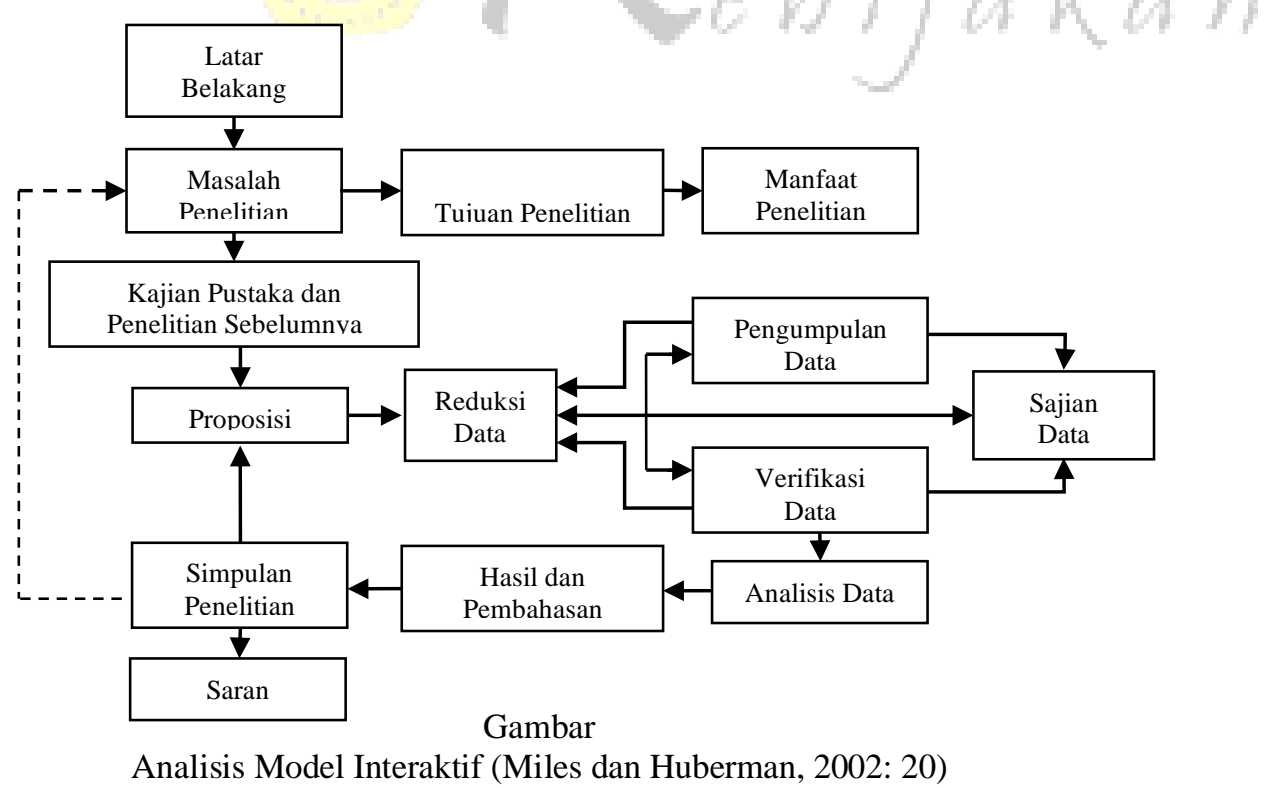

\section{PEMBAHASAN}

Pembahasan pada konteks factor-faktor Implementasi Kebijakan Jaminan Kesehatan Daerah Di Kota Bekasi, peneliti akan membahas berdasarkan hasil kajian teori, analisis, observasi, dan wawancara serta studi dokumentasi seperti yang dideskripsikan di bawah ini. Berdasarkan hasil peneltian, bahwa kebijakan Jaminan Kesehatan Daerah (Jamkesda) Kota Bekasi, yang dikelola pemerintah daerah untuk memberikan pelayanan kesehatan paripurna dalam peningkatan derajat kesehatan masyarakat, telah disesuaikan dengan kebutuhan dan kemampuan pemerintah daerah Kota Bekasi. Jamkesda, juga telah memberikan kontribusi positif dalam membangun kesadaran dan kesehatan masyarakat. Salah satu yang menjadi permasalahan kesehatan selama ini, adalah telah tertanganinya program Jamkesda dan terbukti dengan pencapaian pemerintah Kota Bekasi menjadi predikat "Smart Governance" sebagai penunjang dari sisi pemerintahan yakni bagaimana dapat melayani publik secara terpadu dan paripurna, serta yang terpenting adalah birokrasi yang transparan dan tidak menyulitkan masyarakat. Selain itu, juga memiliki strategi dan pandangan politik yang jelas 
Kebijakan: Jurnal Ilmu Administrasi

Volume 12, Nomor 2, Juni 2021

E-ISSN: 2656-2820

P-ISSN 1829-5762

dan bermanfaat bagi publik. Faktor-faktor dalam implementasi kebijakan yang dimaksudkan adalah sebagai berikut :

\section{Faktor Ukuran dan Tujuan Kebijakan}

Program Kartu Sehat berbasis NIK merupakan program yang setara dengan layanan kesehatan kelas tiga, dan menjadi program unggulan untuk warga Kota Bekasi, karena warga yang membutuhkan sangat tertolong dengan adanya layanan kesehatan masyarakat yang berbasis biaya yang disiapkan oleh APBD Pemerintah Kota Bekasi. Dengan adanya Peraturan Presiden Nomor 82 Tahun 2018 mengenai Jaminan Kesehatan Masyarakat penyelenggaraan Jaminan Kesehatan Daerah, harus di integrasikan dengan Jaminan Kesehatan Nasional yang di kelola BPJS Kesehatan.

Tujuan dari kebijakan dalam pemerintahan daerah tiada lain untuk memberikan yang terbaik bagi rakyat. Dalam hal ini adalah program Kartu Sehat berbasis NIK yang lebih efisien. Hasil analisis peneliti dan observasi lapangan, terdapat perbedaan yang efisien jauh lebih besar antara Kartu Sehat berbasis NIK dengan BPJS Kesehatan. Jika di integrasikan ke BPJS Kesehatan, maka sakit maupun tidak sakit, Pemerintah Kota Bekasi harus membayar iuran selama satu tahun kurang lebih sebesar Rp. 996 miliar, dan apabila dikelola sendiri oleh Dinas Kesehatan Kota Bekasi dengan kerjasama rumah sakit swasta dihitung selama satu tahun kurang lebih sekitar Rp 380 miliar. Berarti ada efisiensi anggaran sebesar Rp.500 miliar. Anggaran ini tentunya dapat digunakan untuk membangun fasilitas kesehatan atau Puskesmas, Rumah Sakit, dan sarana prasarana pelayanan lainnya.

Bekasi Sehat adalah pemerataan dan perluasan akses memperoleh layanan kesehatan bagi masyarakat miskin, melalui penerapan subsidi untuk layanan kesehatan bagi penduduk miskin, korban wabah, dan korban bencana. Dalam hal ini, masyarakat perlu menyimak bahwa prinsip utama Bekasi Sehat adalah pemerataan dan perluasan akses, serta peningkatan layanan kesehatan di Kota Bekasi, sedangkan kartu hanya bersifat instrument. Konsep Bekasi Sehat memang lebih awal dibandingkan pengaturan secara nasional, baik Undang-Undang (UU Nomor 24 Tahun 2011 tentang Badan Penyelenggara Jaminan Sosial (BPJS) maupun Peraturan Presiden (yang telah diubah terakhir kali dengan Perpres Nomor 75 Tahun 2019 tentang Jaminan Kesehatan.

Gagasan pemerataan dan perluasan akses memperoleh layanan kesehatan bagi masyarakat miskin di Kota Bekasi, sejak tahun 2008 dilandasi oleh UU Nomor 40 Tahun 2004 tentang Sistem Jaminan Sosial saat itu, dan program pemerataan dan perluasan akses memperoleh layanan kesehatan bagi masyarakat miskin di Kota Bekasi, yang sudah digagas sejak tahun 2008, ditindaklanjuti oleh Kepala Daerah terpilih periode Tahun 2013-2018 (Rahmat Effendi dan Ahmad Syaikhu), baru diwujudkan kedalam bentuk "Kartu" yakni Kartu Bekasi Sehat (yang kemudian bernama Kartu Sehat Berbasis NIK) sejak tanggal 26 Juli 2017. Gagasan yang semula bersumber dari aspirasi publik, lalu kemudian diimplementasikan kedalam bentuk Kebijakan, semisal Kartu Jakarta Sehat (KJS) pada tahun 2012, dan Kartu Indonesia Sehat (KIS) pada tahun 2014, demikian pula Kartu Bekasi Sehat (KBS) pada tahun 2017, tidak lepas dari opini dan cemooh yang menuding sebagai kebijakan pencitraan dan lain sebagainya.

Menurut masyarakat Kota Bekasi pengguna KS-NIK, adanya kartu sehat sangat membantu kami masyarakat kecil dalam berobat ke rumah sakit, meski fungsinya sama dengan BPJS tetapi KSNIK angat menolong sekali karena tidak membebani masyarakat, dan kartus tersebut tidak dipungut iuran. Hasil analisis terhadap program KS-NIK Pemerintah Kota Bekasi, bahwa KS-NIK sudah berdasar Keputusan Mahkamah Konstitusi. Keputusan itu tertera dalam Nomor 007/PUU-III/2005 tentang Jaminan Sosial memberi jalan bagi pemerintah daerah untuk mengembangkan program 
Kebijakan: Jurnal Ilmu Administrasi

Volume 12, Nomor 2, Juni 2021

E-ISSN: 2656-2820

P-ISSN 1829-5762

jaminan kesehatan sebagai sub sistem jaminan sosial di daerahnya. Di tahun 2020 Kartu Sehat berbasis NIK masih berlaku atau masih dapat digunakan untuk warga Kota Bekasi.

\section{Faktor Sumber daya Kebijakan}

Sumber daya kebijakan (policy resources) tidak kalah pentingnya dengan komunikasi. Sumber daya kebijakan ini harus juga tersedia dalam rangka untuk memperlancar administrasi implementasi suatu kebijakan. Sumber daya ini terdiri atas dana atau insentif lain yang dapat memperlancar pelaksanaan (implementasi) suatu kebijakan. Kurangnya atau terbatasnya dana atau insentif lain dalam implementasi kebijakan, adalah merupakan sumbangan besar terhadap gagalnya implementasi kebijakan. Sejalan dengan pemanfaatan Kartu Sehat (KS) yang telah dirasakan warga Kota Bekasi selama ini, maka kebijakan KS telah dipandang oleh sejumlah Kepala Daerah maupun lembaga legislatif Kabupaten/Kota lain yang melakukan studi banding ke Kota Bekasi, sebagai kebijakan yang mampu menegakkan makna penjaminan kesehatan yang sebenarnya, berupa subsidi penuh atas pembayaran layanan kesehatan bagi warga Kota Bekasi. Komitmen dan kinerja aparatur Pemerintah Kota (Pemkot) Bekasi, telah mampu mengimplementasikan kebijakan KS sepanjang tahun 2018 dan tahun 2019, selain itu dukungan biaya dari APDB merupakan dukungan nyata dari pemerintah daerah untuk kepentingan masyarakat. Sarana pendukung KS-NIK juga penting untuk menyukseskan program KS-NIK.

Berdasarkan hasil diskusi melalui Focus Group Discussion (FGD) yang digelar peneliti yang dihadiri beberapa SKPD Kota Bekasi, anggota DPRD Kota Bekasi, instansi terkait, akademisi, dan tokoh masyarakat Kota Bekasi, dari fakta lapangan bahwa program KS-NIK atau Jaminan Kesehatan Daerah (Jamkesda) yang di biaya APBD Kota Bekasi sangat membantu kaum miskin waga Kota Bekasi. Program tersebut, cukup signifikan dan memberikan dampak positif terhadap kesehatan masyarakat perkotaan Kota Bekasi. Namun dapat terjaminnya akuntabilitas maka perlu memperhatikan hal-hal yang perlu direspon terhadap isu sosial dan politik berkaitan dengan akuntabilitas anggaran, validitas pengguna KS, dan standarisasi pelayanan dan harga yang diterapkan oleh rumah sakit.

Sumber daya manusia, sumber dana atau biaya yang digunakan, insentif dan sarana yang digunakan merupakan unsur untuk mendukung program KS-NIK yang berperan besar dalam meningkatkan derajat kesehatan masyarakat. Faktor sumber daya ini boleh dikatakan masih belum berjalan secara efektif dalam mengimplementasikan program KS-NIK ini. Langkah konkrit yang harus dilakukan adalah agar sumber daya manusia, sumber dana dan insentif pelaksana dapat terpenuhi baik secara kuantitas maupun kualitasnya sehingga implementasikan kebijakan atau program tersebut di atas terlaksana sesuai harapan pemerintah daerah dan masyarakat Kota Bekasi. Keberhasilan KS-NIK yang diterapkan di suatu negara bergantung dari pencapaian berbagai faktor dalam jaminan kesehatan tersebut, seperti pelayanan kesehatan, sumberdaya manusia dan anggaran, sumber daya peralatan kesehatan, dan regulasi. Sinergi antara semua faktor tersebut, yang mendukung pelaksanaan jaminan kesehatan agar berjalan dengan baik.

Kebijakan yang ditetapkan pemerintah daerah Kota Bekasi memeberikan dampak yang signifikan terhadap perbaikan kesejahteraan melalui kesehatan masyarakat dengan program KS-NIK. Dalam setiap program pemerintah daerah, setiap individu dan kelompok akan memiliki persepsi dan penilaian yang berbeda terhadap suatu bentuk kebijakan. Kekecewaan maupun tekanan yang mungkin timbul akibat persepsi dan penilaian terhadap suatu bentuk kebijakan akan memunculkan bentukbentuk perilaku yang akan mempengaruhi kinerja pemerintah, namun dengan komitmen pemerintah 
Kebijakan: Jurnal Ilmu Administrasi

Volume 12, Nomor 2, Juni 2021

E-ISSN: 2656-2820

P-ISSN 1829-5762

daerah dan seluruh perangkatnya berkeyakinan bahwa program KS-NIK adalah program kepentingan masyarakat, maka berangkat dari keyakinan tersebut, KS-NIK akan berjalan dengan baik dan akuntabilitasnya dapat dipertanggung jawabkan.

\section{Faktor Karakteristik Agen Pelaksana}

Karakteristik agen pelaksana meliputi organisasi formal dan organisasi informal yang akan terlibat dalam pengimplementasian kebijakan atau Program KS-NIK di Kota Bekasi ini. Hal ini penting karena kinerja implementasi kebijakan akan sangat dipengaruhi oleh ciri yang tepat serta cocok dengan para agen pelaksananya. Hal ini berkaitan dengan konteks kebijakan yang akan dilaksanakan pada beberapa kebijakan dituntut pelaksana kebijakan yang ketat dan disiplin

Sebuah arahan positif semestinya dapat membentuk kearifan bersikap bagi warga Kota Bekasi dalam merespon selanjutnya perihal penghentian sementara, upaya penyesuaian, dan keberlanjutan Program Jamkesda KS-NIK. Kebersamaan dan kearifan aparatur eksekutif dan legislatif di Kota Bekasi menjadi modal penting untuk mengimplementasikan kebijakan pemerataan dan perluasan akses memperoleh layanan kesehatan bagi warga Kota Bekasi, dengan sebaik-baiknya, dengan memperhatikan sinkronisasi kebijakan. Hal yang perlu ditegaskan, bahwa program Jamkesda KS-NIK dihentikan sementara terhitung tanggal 1 Januari 2020, pada hakikatnya merupakan ketaatan terhadap Kebijakan Jaminan Kesehatan Nasional (JKN). Namun dipastikan program tersebut dapat dilanjutkan kembali seiiring dengan adanya Keputusan Mahkamah Konstitusi (MK) Nomor 007/PUU-III/2005 tetap memberikan ruang bagi Pemerintah Daerah untuk dapat menyelenggarakan sub sistem jaminan sosial di daerahnya sepanjang bersifat melengkapi (complementary) dan tidak saling tumpang tindih dengan program Jaminan Sosial yang telah diselenggarakan oleh Pemerintah Pusat.

Program Pembiayaam Berbasis NIK 2020, masih tetap meliputi pelayanan kesehatan di seluruh Puskesmas Kota Bekasi, pelayanan rawat jalan di rumah sakit yang bekerjasama atas dasar rujukan dari Puskesmas, dan pelayanan rawat inap Kelas III di rumah sakit. Dinas Kesehatan Kota Bekasi juga sudah mulai mensosialisasikan pemberlakuan KS NIK dengan aturan terbaru. Dalam program pembiayaan kesehatan berbasis NIK, Pemkot Bekasi telah bekerjasama dan menjalin MOU dengan 47 rumah sakit. Terdiri dari 37 RS di wilayah Kota Bekasi dan 10 RS di luar Kota Bekasi.

Karakteristik agen pelaksana yang dimaksud adalah mencakup struktur birokrasi dan mekanisme kerja sehingga prosedur kerja dn koordinasi antar instansi atau lembaga dalam implementasi kebijakan atau Program KS-NIK di semua aspek pelayanan masyarakat sangat diperlukan. Hasil penelitian membuktikan bahwa dengan karakeristik dari agen pelaksana ini belum menunjukan hasil yang efektif, sehingga masalah yang dihadapi berkaitan dengan implementasi kebijakan Program Jaminan Kesehatan Daerah Bagi Masyarakat Berbasis Kartu Keluarga dan Nomor Induk Kependudukan di Kota Bekasi, belum dapat memberikan pelayanan berkualitas sesuai harapan pemerintah dan masyarakat. Langkah konkrit yang harus dilakukan adalah agar prosedur kerja dapat dilaksanakan dengan benar dan konsisten dan koordinasi antar lembaga atau organisasi pelaksana yang menjalankan program kebijakan tersebut di atas dapat berjalan sebagaimana mestinya sesuai aturan yang berlaku, sehingga implementasikan kebijakan atau program tersebut dapat terpenuhi sesuai dengan kebutuhan pemerintah daerah dan masyarakat Kota Bekasi.

\section{Faktor Sikap/disposisi para pelaksana}

Sikap penerimaan atau penolakan dari agen pelaksana kebijakan sangat mempengaruhi keberhasilan atau kegagalan implementasi kebijakan publik. Hal ini sangat mungkin terjadi karena kebijakan yang dilaksanakan bukanlah hasil formulasi warga setempat yang mengenal betul 
Kebijakan: Jurnal Ilmu Administrasi

Volume 12, Nomor 2, Juni 2021

E-ISSN: 2656-2820

P-ISSN 1829-5762

permasalahan dan persoalan yang mereka rasakan. Terdapat tiga macam elemen respon yang dapat mempengaruhi kemampuan dan kemauannya untuk melaksanakan suatu kebijakan, antara lain terdiri dari pertama, pengetahuan (cognition), pemahaman dan pendalaman (comprehension and understanding) terhadap kebijakan, kedua, arah respon merekaapakah menerima, netral atau menolak (acceptance, neutrality, and rejection), dan ketiga, intensitas terhadap kebijakan.

Beberapa stakeholder, dari PGD terungkap bahwa, intinya kebijakan KS-NIK guna memberikan pelayanan yang sama tanpa diskriminatif. Sebab itu, kedudukan, kewenangan, dan kesadaran implementator dalam merespon kepentingan masyarakat dalam hal ini program KS-NIK menjadi prioritas. Tujuan kebijakan KS-NIK tidak harus diukur dengan sesaat, namun harus dilihat dari dampak yang ditimbulkan dari kebijakan tersebut. Apakah kebijakan yang dilakukan pemkot Bekasi mampu mengakomodir kepentingan masyarakat. Tujuan akhirnya, bahwa KS-NIK mampu menciptakan manusia Indonesia yang sehat. Itu sebabnya, faktor yang menyebabkan implementasi kebijakan Jaminan Kesehatan Daerah Kota Bekasi belum berjalan efektif, karena keputusan yang diambil belum sejalan dengan kepentingan politik yang ada di pemerintahan pusat.

Arahan dan kewenangan pelaksana dalam implementasi kebijakan KS-NIK ini sering jadi persepsi berbeda sehingga berdampak kepada hasil yang diharapkan. Seringkali adanya informasi dari pihak pelaksana yang disampaikan kepada masyarakat janggal dan kurang dipahami oleh masyarakat. Implementasi kebijakan juga berkait dengan kemampuan sumber daya manusia, dimana kebijakan yang ada di atas kertas bukan merupakan kebijakan dalam praktek, tetapi dibutuhkan kesadaran dan arahan pelaksana sehingga kebijakan yang menjadi tujuan dan tetap sasaran.

Berdasarkan hasil analisis bahwa secara konseptual implementasi kebijakan berkaitan dengan program Jaminan Kesehatan Daerah peningkatan kualitas kesehatan di Kota Bekasi dapat dijalankan secara gradual dan berkelanjutan yang didukung oleh kesadaran pelaksanaan dengan arahan pelaksanaan serta intensitas tanggung jawab pelaksana, sehingga kebijakan tersebut dapat terbangun dengan baik yaitu tercapaiannya kepuasan masyarakat di Kota Bekasi.

\section{Faktor Komunikasi Antar Organisasi}

Organisasi kerap kali dipahami sebagai sebuah sistem yang kompleks dengan bagian-bagian di dalamnya saling berinteraksi satu sama lain, yang memfokuskan pada tingkah hubungan yang bersifat organisasi. Demikian pula, dengan KS-NIK yang merupakan upaya pemerintah Kota Bekasi dalam memberikan pelayanan kesehatan bagi seluruh rakyatnya. KS-NIK yang digunakan oleh warga Kota Bekasi tanpa harus membayar premi atau iuran dan tanpa menggunakan rujukan jika ingin menggunakan fasilitas kesehatan di rumah sakit yang telah bekerjasama dengan pemerintah daerah.

Hubungan antar bagian dalam organisasi perlu diatur agar komunikasi para pelaksana dapat berjalan dengan baik, konsisten dan keseragaman dalam melakukan komunikasi kerja dengan bagian yang lain. Jangan sampai terjadi ketika ada sesuatu yang kurang maka menyebabkan proses produksi jadi terganggu. Ini tujuan dari membangun sistem komunikasi kerja dalam pemerintahan ketika merealisasikan sebuah program seperti KS-NIK di Kota Bekasi. Karena bila ada suatu permasalahan bisa segera diatasi dengan cepat karena sumber kesalahan atau kekurangannya juga bisa langsung diketahui. Dalam banyak hal, bentuk kontrol sosial dapat dilakukan dengan melakukan interaksi baik secara langsung maupun tidak langsung antara pimpinan dan bawahan. Untuk mencapai tujuan organisasi diperlukan adanya suatu proses interaksi yang melibatkan semua anggota dari level atas (pimpinan) hingga level bawah (karyawan) atau bawahan. Tujuan organisasi, akan tercapai dengan 
Kebijakan: Jurnal Ilmu Administrasi

Volume 12, Nomor 2, Juni 2021

E-ISSN: 2656-2820

P-ISSN 1829-5762

baik apabila adanya sistem komunikasi yang baik yang dapat menjembatani antara anggota dalam berinteraksi satu sama lain, sehingga tidak terjadi pengelompokan.

Integrasi program dengan pusat yakni namanya pembiayaan layanan kesehatan bagi warga Kota Bekasi berbasis NIK. Nanti jalan, di antara bagian-bagian yang tidak dicover oleh BPJS. Misalnya pasien sakit, oleh BPJS hanya ditanggung 2 kali kontrol. Tapi dokter memberi rekomendasi 4 kali kontrol. Kekurangannya ini yang dilengkapi KS-NIK. Skema seperti itu merupakan bentuk integrasi KS-NIK sebagai jaminan kesehatan daerah dengan BPJS Kesehatan sebagai jaminan kesehatan nasional. Tekad pemerintah Kota Bekasi mempertahankan KS-NIK sebagai program kesehatan dengan manfaat yang sama persis dengan BPJS Kesehatan. Selain berpotensi menimbulkan kerugian negara karena anggaran dan klaim ganda rumah sakit terhadap KS-NIK dan BPJS kesehatan, warga Kota Bekasi juga tak dijamin akan dilayani ketika sakit di luar kemampuan Pemkot Bekasi. Tanpa integrasi ke BPJS dan cuma mengandalkan Jamkesda. Model inilah yang harus dikomunikasikan dengan baik kepada semua pihak agar dipahami secara bersama.

Dalam konteks organisasi, arus komunikasi mengalir secara formal mengikuti saluran formal sesuai disain struktur organisasi dimaksud, salah satu jaringan komunikasi formal adalah organisasi adalah arus komunikasi vertikal yang mencakup komunikasi ke atas (upward communication), komunikasi ke bawah (downward communication) dan komunikasi ke samping (horizontal communication). Komunikasi yang baik dengan rekan sekerja akan sangat membantu untuk berkoordinasi mengenai pekerjaan. Terutama di sebuah perusahan distribusi penjualan yang sebagian anggotnya harus bekerja sama baik di dalam maupun di luar perusahaan. Maka fungsi kejujuran dalam berkomunikasi antar rekan kerja terutama terkait dengan penyelesaian pekerjaan menjadi sangat penting.

\section{Faktor Lingkungan ekonomi, sosial dan politik}

Dalam konteks penyelenggaraan jaminan kesehatan KS-NIK Kota Bekasi, bahwa lingkungan ekonomi, sosial dan politik harus sejalan sehingga tidak terjadi kesalahan ketika pelaksanaan program yang diyakini menjadi solusi kesehatan bagi 2,6 juga masyarakat Kota Bekasi. Hal ini mengingat Kota Bekasi sebagai kota setelit yang mana kemajemukan penduduk sudah terbangun dengan baik. Faktor sosial,budaya dan politik tumbuh sejalan dengan pertumbuhan ekonomi kota, dimana APBD Kota Bekasi pada tahun 2019 mencapai Rp.6,4 trilyun. Hl ini membuktikan bahwa Kota Bekasi selain kota penyangga Ibu Kota Jakarta, juga sebagai kota dengan pertumbuhan dan dinamisasi ekonomi yang terus meningkat. Kota Bekasi pluralistic telah terbentuk nilai=nilai keberagaman,sikap toleransi dan pemahaman akan nilai-nilai pluralistic menjadi acuan masyarakat Kota Bekasi yang tetap terjaga dengan baik.

Toleransi bagi masyarakat Kota Bekasi merupakan sikap yang melarang adanya diskriminasi dalam konteks sosial,budaya dan keagamaan terhadap kelompok-kelompok yang berbeda dalam masyarakat. Toleransi dalam lingkup keagamaan merupakan sikap yang membiarkan, sabar dalam menghadapi perbedaan mengenai hal keagamaan cenderung tidak memaksakan apa yang telah diyakininya pada orang lain. Berangkat di situlah, setiap program unggulan dari Pemerintah Kota Bekasi selalu mendapat dukungan rakyat yang diinterpretasikan melalui DPRD Kota Bekasi. Salah satu contoh proram unggulan yang mendapat pengawalan ketat dari rakyat Kota Bekasi adalah penggunaan KS-NIK bagi masyarakat Kota Bekasi.

Jamkesda Kota Bekasi sudah memberikan manfaat yang sangat besar bagi masyarakat. Masyarakat merasa terlayani dan terpenuhi kebutuhannya ketika sakit. Kemudahan akses menjadikan 
Kebijakan: Jurnal Ilmu Administrasi

Volume 12, Nomor 2, Juni 2021

E-ISSN: 2656-2820

P-ISSN 1829-5762

program KS-NIK sangat diharapkan masyarakat Kota Bekasi. Kebijakan pelayanan kesehatan berbasis KS-NIK ini patut diapresiasi. Apalagi sudah terbukti memberikan dampak postif dalam pelayanan kesehatan di Kota Bekasi. Namun, amat disayangkan masih saja ada pihak-pihak yang berusaha menghalang-halangi keberlanjutan program pelayanan kesehatan berbasis KS-NIK. Pihakpihak yang berupaya menghambat keberlanjutan pelayanan kesehatan berbasi KS-NIK tidak memiliki empati pada penderitaan rakyat. Keberpihakan mereka pada kesusahan rakyat patut dipertanyakan. Harusnya program ini didukung tanpa dihalang-halangi secara ekonomi, sosial dan politik karena tujuan dari program ini menjamin pelayanan kesehatan kepada rakyat.

Melaksanakan fungsi pelayanan, lingkungan sosial masyarakat dan kondisi kehidupan masyarakat, tetap menjadi daya dukung terhadap kepuasan masyarakat. Peningkatan kualitas pelayanan dengan kepuasan masyarakat yang dilakukan oleh Pemda Kota Bekasi melalaui Dinas Kesehatan dan RSUD Kota Bekasi serta RS rujukan lainnya merupakan salah satu tolok ukur keberhasilan tata kelola pelayanan pada bidang kesehatan. Peningkatan kualitas kepuasaan masyarakat dalam pelayanan masyarakat sangat krusial yang dihadapi oleh Pemda Bekasi. Di satu sisi terdapat tuntutan yang lebih gencar dari masyarakat agar di era otonomi daerah ini, maka Pemda Kota Bekasi melalui Program KS-NIK ini dapat meningkatkan kualitas pelayanannya seperti yang selama ini mereka harapkan. Tuntutan ini didasarkan pada pengalaman yang selama ini berkembang dan mereka alami. Dalam kenyataannya, masih banyak dijumpai permasalahan yang berkaitan dengan pemberian pelayanan bidang kesehatan kepada masyarakat di Kota Bekasi.

Peneliti menemukan kebaharuan (novelty) agar implementasi kebijakan/Program Jaminan Kesehatan Daerah Bagi Masyarakat Berbasis Kartu Keluarga dan Nomor Induk Kependudukan di Kota Bekasi berjalan secara efektif adalah sebagai berikut :

1. Dapat mengiintegrasikan kebijakan/ program kesehatan dari Pemerintah Pusat dengan program kesehatan dari Pemerintah Daerah Kota Bekasi sehingga tidak ada double cost anggaran yang diberlakukan secara bersamaan. Hal ini juga tentunya didukung oleh koordinasi yang berkelanjutan antara Pemerintah Pusat dengan Pemerintah Daerah Kota Bekasi.

2. Adanya sosialisasi kepada masyarakat tentang manfaat dan prosedur Program Jaminan Kesehatan Daerah Bagi Masyarakat Berbasis Kartu Keluarga Dan Nomor Induk Kependudukan, sehingga tingkat pengetahuan masyarakat akan kebaikan/ program kesehatan tersebut meningkat.

3. Kebijakan publik sebagai instrumen yang mensinergikan peran pemerintah dan publik harus dapat berjalan secara optimal. Untuk itu diperlukan inovasi kebijakan yang secara substantif dapat memberikan penguatan dalam menyelesaikan permasalahan di tengah masyarakat. Dengan mengkonseptualisasikan sinergitas antar stakeholder implementasi kebijakan, maka diharapkan dapat menjelaskan dan mengetahui apakah implementasi kebijakan dalam mewujudkan tujuan-tujuan dari kebijakan yang telah digariskan dapat dikatakan gagal atau berhasil dalam mencapai tujuannya.

\section{SIMPULAN}

Berdasarkan hasil penelitian dan pembahasan, maka peneliti dapat menyimpulkan beberapa hal adalah bahwa terdapat faktor-faktor dalam mengimplementasi kebijakan Jaminan Kesehatan 
Kebijakan: Jurnal Ilmu Administrasi

Volume 12, Nomor 2, Juni 2021

E-ISSN: 2656-2820

P-ISSN 1829-5762

Daerah Kota Bekasi yaitu faktor standar, ukuran dan tujuan kebijakan, ukuran dan tujuan kebijakan, sumber-sumber daya, karakteristik organisasi pelaksana, sikap para pelaksana, komunikasi antar organisasi terkait dan kegiatan-kegiatan pelaksanaan, dan lingkungan sosial, ekonomi serta politik. Namun dalam implementasinya faktor-faktor tersebut belum seluruhnya berjalan secara efektif, yaitu faktor sumber daya kebijakan dan dan faktor karakteristik agen pelaksana sehingga masih terdapat masalah yang dihadapi berkaitan dengan implementasi kebijakan Jaminan Kesehatan Daerah.

Hal ini tentunya juga belum dapat memberikan jalan terbaik dalam memberikan pelayanan publik yang berkualitas khususnya berkaitan dengan Program Jaminan Kesehatan Daerah Bagi Masyarakat Berbasis Kartu Keluarga dan Nomor Induk Kependudukan baik. Disamping itu pula peneliti menemukan kebaharuan (novelty) agar implementasi kebijakan/Program Jaminan Kesehatan Daerah Bagi Masyarakat Berbasis Kartu Keluarga dan Nomor Induk Kependudukan di Kota Bekasi berjalan secara efektif adalah dengan aspek integritas,sosialisasi dan sinergitas.

\section{DAFTAR PUSTAKA}

Abidin, Said Zainal. 2006. Kebijakan Publik. Jakarta: Suara Bebas.

Denhardt, Janet Vinzant and Denhardt, Robert B. 2004. The New Public Service: Serving, Not Steering. New York: M. E. Sharpe.

Dunn, William N. 2000. Analisis Kebijakan Publik. Terjemahan Darwin, Muhajir. Yogyakarta: Gadjah Mada University Press.

Edward III, Milton J. 2000. Implementing Public Policy. Connecticut Kumarian Press

Grindle, Merilee S. , 1980. Politics and Apolicy Implementation in the Third World, New Jersey: Princetown University Press.

Howlett, Michael \& M Ramesh. 1995. Studying Public Policy: Policy Cycles and Policy Subsystem. Oxford University Press.

Islamy, M. Irfan. 2001. Prinsip-prinsip Perumusan Kebijakan Negara. Jakarta: Bumi Aksara.

Mazmanian, Daniel H \& Paul A Sabatier (eds). 1983. Effective Policy Implementation. Lexington Mash DC, Heath.

Nugroho Dwijowijoto, Riant. 2004. Kebijakan Publik: Formulasi, Implementasi dan Evaluasi. Yogyakarta: PT. Elex Media Komputindo.

Pressman, Jeffrey, L. Wildavsky, Aaron, B. 1973. Implementation. Barkely California: University of California Press.

Sugiono. 1999. Metode Penelitian Administrasi. Bandung: Alfabeta Bandung.

Van Metter, Donalds \& Carl E Van Horn. 2002. The Policy Implementation Process: A Conceptual Framework Adminitration Society. Vol. 6 No. 4 February.

Vigoda, Eran. 2002. Public Adminstration, An Interdisciplinary Critical Analysis, Marcell Decker Inc. , New York.:

Wahab, Solichin Abdul. 2002. Analisis Kebijakan, dari Formulasi ke Implementasi Kebijakan Negara. Jakarta: Bumi Aksara. 
Kebijakan: Jurnal Ilmu Administrasi

Volume 12, Nomor 2, Juni 2021

E-ISSN: 2656-2820

P-ISSN 1829-5762

Waldo, Dwight. 2006. Public Administration. Terjemahan Slamet W. Admosoedarmo. Jakarta: Bumi Aksara.

Winarno, Budi. 2002. Teori dan Proses Kebijakan Publik. Yogyakarta: MedPress.

Widodo, 2007. Analisis Kebijakan Publik: Konsep dan Aplikasi. Surabaya: Bayumedia

Winarno, Budi. 2002. Teori dan Proses Kebijakan Publik. Yogyakarta: MedPress.

Widodo, 2007. Analisis Kebijakan Publik: Konsep dan Aplikasi. Surabaya: Bayumedia

Dokumen lain:

Undang-Undang No 36 Tahun 2009 tentang Kesehatan

Undang-Undang Nomor 40 Tahun 2004 tentang Sistem Jaminan Sosial Nasional (SJSN)

Undang-Undang Nomor 24 tahun 2011 tentang Badan Penyelenggara Jaminan Sosial (BPJS)

Undang-undang nomor 32 tahun 2004 tentang Otonomi Daerah

Peraturan Walikota Bekasi Nomor 27. A Tahun 2017 Tentang Penyelenggaraan Program Jaminan

Kesehatan Daerah Bagi Masyarakat Berbasis Kartu Keluarga Dan Nomor Induk Kependudukan di Kota Bekasi 